\title{
A familial syndrome of hypothalamic hamartomas, polydactyly, and $S M O$ mutations: a clinical report of 2 cases
}

\author{
Sebastian Rubino, MD, ${ }^{1}$ Jiang Qian, MD, PhD, ${ }^{2}$ Carlos D. Pinheiro-Neto, MD, PhD, ${ }^{3}$ \\ Tyler J. Kenning, MD, 1 and Matthew A. Adamo, MD'1 \\ Departments of ${ }^{1}$ Neurosurgery and ${ }^{2}$ Pathology, and ${ }^{3}$ Division of Otolaryngology, Albany Medical Center, Albany, New York
}

\begin{abstract}
Hypothalamic hamartomas are benign tumors known to cause gelastic or dacrystic seizures, precocious puberty, developmental delay, and medically refractory epilepsy. These tumors are most often sporadic but rarely can be associated with Pallister-Hall syndrome, an autosomal dominant familial syndrome caused by truncation of glioblastoma transcription factor 3, a downstream effector in the sonic hedgehog pathway. In this clinical report, the authors describe two brothers with a different familial syndrome. To the best of the authors' knowledge, this is the first report in the literature describing a familial syndrome caused by germline mutations in the Smoothened (SMO) gene and the first familial syndrome associated with hypothalamic hamartomas other than Pallister-Hall syndrome. The authors discuss the endoscopic endonasal biopsy and subtotal resection of a large hypothalamic hamartoma in one of the patients as well as the histopathological findings encountered. Integral to this discussion is the understanding of the hedgehog pathway; therefore, the underpinnings of this pathway and its clinical associations to date are also reviewed.
\end{abstract}

https://thejns.org/doi/abs/10.3171/2018.7.PEDS18292

KEYWORDS hypothalamic hamartoma; Smoothened gene; SMO; Chiari malformation type I; gelastic/dacrystic seizures; oncology

$\mathrm{H}$ YPOTHALAMIC hamartomas are benign tumors that arise from the ventral hypothalamus and tuber cinerum..$^{11}$ They can be either pedunculated, parahypothalamic masses that project below the hypothalamus or sessile, or intrahypothalamic masses that have broadbased attachment and involve the lateral walls of the third ventricle. ${ }^{1}$ They arise during fetal development and cause gelastic (laughing) seizures, dacrystic (crying) seizures, precocious puberty, developmental delay, and medically refractory epilepsy in the pediatric population.,18 Their prevalence is approximately 1 in 200,000 children. ${ }^{6}$

Most hypothalamic hamartomas are sporadic and occur without prior family history. In contrast, approximately 5\% are associated with Pallister-Hall syndrome, an autosomal dominant familial syndrome consisting of hypothalamic hamartomas, postaxial polydactyly, and imperforate anus, with some patients having a laryngeal cleft, abnormal lung lobulation, renal dysplasia or agenesis, shortened metacarpals, nail dysplasia, multiple buccal frenula, hypoadrenalism, hypopituitarism, microcephaly, congenital heart defects, and intrauterine growth retardation. ${ }^{12}$ Pallister-Hall syndrome was previously the only familial syndrome associated with hypothalamic hamartomas. It is caused by a germline truncation mutation of the glioblastoma transcription factor (GLI3) gene and subsequent truncation of the GLI3 protein, a downstream transcription factor within the hedgehog $(\mathrm{Hh})$ pathway. ${ }^{19}$

In this paper we present a new familial syndrome associated with hypothalamic hamartomas, postaxial polydactyly/syndactyly, Chiari I malformation, microcephaly, pituitary cyst, short stature, spatulate mandible, mandibular epulis, and language delay. This is the first reported familial syndrome caused by germline mutations in the Smoothened $(S M O)$ gene, which is responsible for production of the SMO protein, a seven-transmembrane, G protein-coupled receptor within the Hh pathway.

\section{Case Reports}

The brothers in this report are of paternal Irish-German

ABBREVIATIONS Dhh = desert hedgehog; $\mathrm{DI}=$ diabetes insipidus; $\mathrm{GFAP}=$ glial fibrillary acidic protein; $\mathrm{GLI}=$ glioblastoma transcription factor; $\mathrm{GRK} 2$ = $\mathrm{G}$ protein-coupled receptor kinase 2; $\mathrm{Hh}=$ hedgehog; Ihh = Indian hedgehog; PTCH = Patched; Shh = sonic hedgehog; SUFU = Suppressor of Fused.

SUBMITTED May 21, 2018. ACCEPTED July 18, 2018.

INCLUDE WHEN CITING Published online October 12, 2018; DOI: 10.3171/2018.7.PEDS18292. 
descent and maternal Irish-Italian descent. Their father had a history of cingulate gyrus cavernoma with associated deep venous anomaly and partial seizures. Additionally, there was a paternal family history of miscarriages, infant deaths, and learning disabilities.

\section{Case 1}

Case 1 was a 6-year-old boy who initially presented with microcephaly, short stature, spatulate mandible, mandibular epulis, and polydactyly/syndactyly of his toes. His mother had a healthy full-term pregnancy, complicated only by maternal deep venous thromboses and morning sickness. The patient was born via spontaneous vaginal delivery. Despite his phenotype, he exhibited age-appropriate motor, language, and social development. MRI was positive for a $12 \times 11 \times 16-\mathrm{mm}$ nonenhancing suprasellar mass, $4 \times$ $8 \times 5-\mathrm{mm}$ nonenhancing pituitary cyst, and a type I Chiari malformation (Fig. 1). A coccygeal dimple was appreciated on examination but subsequent MRI of the spine was negative for any abnormalities. Endocrinological workup was negative. The patient underwent neurogenetic testing and had a negative overgrowth syndromes panel, testing for the following genes: CUL4B, EZH2, GLI3, GPC3, MED12, NFIX, NSD1, PHF6, PTCH, PTEN, and UPF3B. Subsequent whole exome sequence analysis was positive for a heterozygous deletion within chromosome 7q32.1, including part of the $S M O$ gene, and heterozygous for the c.2291_2292delAG variant of unknown significance within the $S M O$ gene.

At age 3 the patient experienced gelastic seizures, which were subsequently well controlled with levetiracetam. All
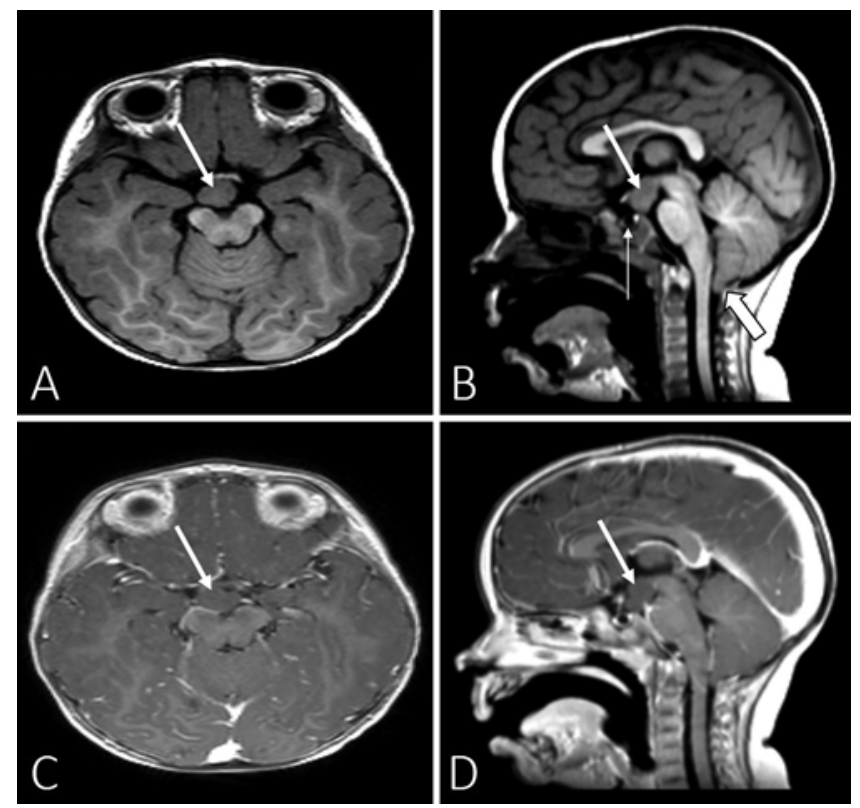

FIG. 1. Case 1. Axial (A) and sagittal (B) noncontrasted T1-weighted MRI sequence, and axial (C) and sagittal (D) contrasted T1-weighted MRI sequence. The thick arrows in each panel demonstrate the $12 \times 11$ $\times 16-\mathrm{mm}$ nonenhancing suprasellar mass. In panel $\mathrm{B}$, the thin arrow demonstrates the $4 \times 8 \times 5-\mathrm{mm}$ nonenhancing pituitary cyst and the thick outlined arrow demonstrates the type I Chiari malformation coming into view. cranial imaging remained stable over the next 3 years and his motor, language, and social development remained ageappropriate and unaffected.

\section{Case 2}

Case 2 was a 3 -year-old boy born after an uncomplicated full-term pregnancy via spontaneous vaginal delivery. He was born with right hand and bilateral feet polydactyly and subsequently underwent digit amputations. He had age-appropriate motor, language, and social development until approximately 2.5 years of age when he began experiencing clustered dacrystic seizures. These episodes lasted approximately 30-60 seconds and consisted of intense emotions of fear or pain, crying with retained consciousness, and arrhythmic, nonsynchronous movements described by his parents as "night terrors." These episodes initially occurred at night when waking from sleep and then progressed to occurring during the day. They occurred in clusters, sometimes up to 12 episodes per day, with subsequent months of seizure freedom. Outpatient electroencephalography was negative for epileptiform activity. He began experiencing mild speech delays at age 3 . MRI was positive for an exophytic, nonenhancing $24 \times 34$ $\times 27-\mathrm{mm}$ suprasellar mass, isointense to gray matter on all sequences (Fig. 2), as well as compression and displacement of the optic nerves and chiasm. Neuroophthalmological evaluation was negative for papilledema or optic nerve atrophy. Endocrinological workup was negative. Like his brother, whole exome sequence analysis revealed a heterozygous partial deletion of the $S M O$ gene within chromosome 7q32.1 and a heterozygous c.2291_2292delAG variant of unknown significance within the $S M O$ gene.

Given the size of the suprasellar mass, progressive dacrystic seizures, and the compression of the optic nerves,
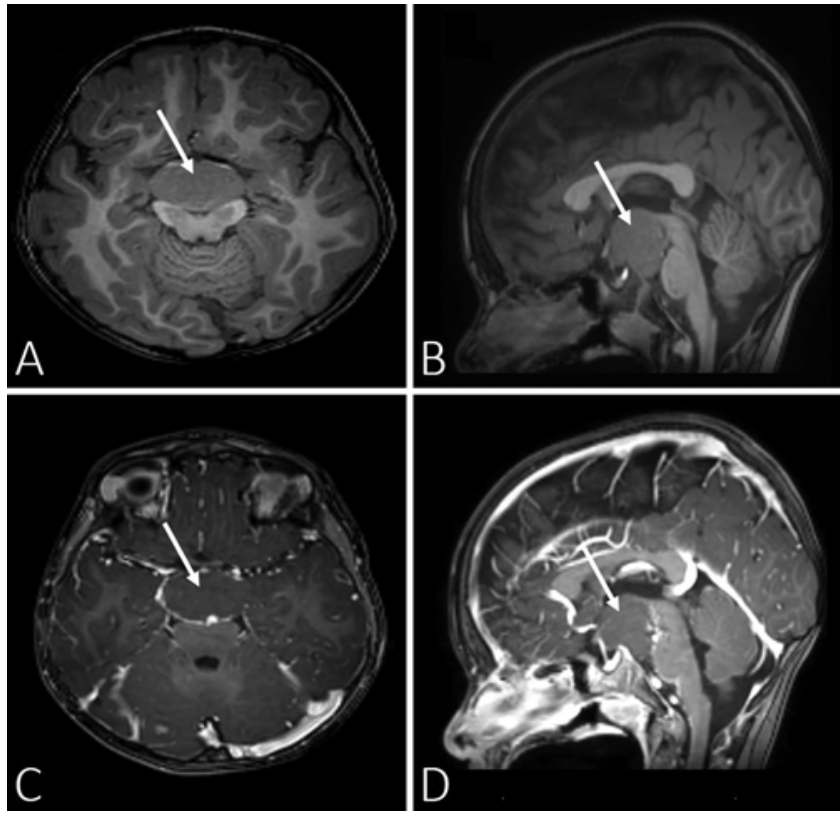

FIG. 2. Case 2. Axial (A) and sagittal (B) noncontrasted T1-weighted MRI sequence, and axial (C) and sagittal (D) contrasted T1-weighted MRI sequence. The arrows in each panel indicate the exophytic, nonenhancing $24 \times 34 \times 27-\mathrm{mm}$ suprasellar mass. 
an extended endoscopic endonasal transsphenoidal transplanum transtuberculum transsellar biopsy and possible debulking of the mass were recommended. Although the patient did not have papilledema or optic nerve pallor, there was concern regarding the inability to accurately perform visual field testing in a child this young and the potential for vision compromise should the mass grow larger. Therefore, the goals of surgery were to confirm the diagnosis, decompress the optic nerves, and help guide subsequent care.

\section{Operation}

We began by harvesting a $4 \times 5-\mathrm{cm}$ autologous fascia lata graft. Then we proceeded with the endonasal portion of the procedure using adult-sized instruments and neuronavigation. The inferior and middle turbinates were lateralized, and a left-sided autologous pedicled, mucoperichondrial, vascularized nasoseptal flap was harvested and placed in the nasopharynx as previously described..$^{30} \mathrm{We}$ next performed a retrograde posterior ethmoidectomy, bilateral sphenoidotomy, and limited posterior septectomy. The intrasphenoidal septations, bony sella, and planum sphenoidale were subsequently drilled away. The dura was widely exposed, cauterized, and incised, giving view to the pituitary gland, stalk, and suprasellar tumor (Fig. 3). The tumor was dissected and debulked by working lateral to the pituitary infundibulum, taking care not to injure any neurovascular structures. Once maximal safe decompression and hemostasis were achieved, cranial base reconstruction was performed using an inlay-onlay fascia lata "button" graft as previously described, ${ }^{25}$ with subsequent placement of the nasoseptal flap. Surgicel (Ethicon) and a thin layer of DuraSeal were applied to the borders of the flap and a piece of nasopore was placed to support the flap and promote its adherence to the cranial base.

\section{Pathological Findings}

The specimen consisted of disorganized hypothalamic

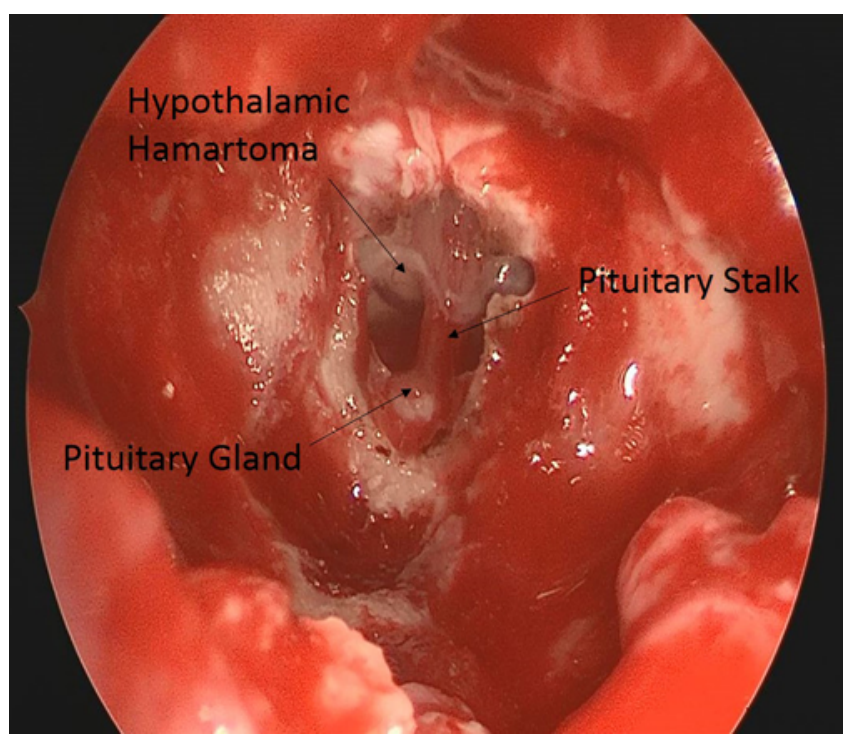

FIG. 3. Case 2. Endoscopic endonasal operative view of the pituitary gland, stalk, and hypothalamic hamartoma after entry through the sphenoid sinus and sella turcica. Figure is available in color online only. tissue with several foci of vague nodularity compatible with a benign hypothalamic hamartoma (Fig. 4A). These nodular foci were composed of loosely packed, mediumsized neurons with pericellular halo embedded in a finely vacuolated neuropil (Fig. 4B, thick arrows) and further highlighted on Neu-N stain (Fig. 4C). Scattered reactive fibrillary astrocytes were found in and around these nodules (Fig. 4B, thin arrows), further highlighted on glial fibrillary acidic protein (GFAP) stain (Fig. 4D). These foci were IDH-1 and p53 negative, and had very low Ki-67 labeling. Stains for neurofilament and synaptophysin revealed no abnormalities. While densely packed neuronal or neuroglial nodules (classically associated with hypothalamic hamartomas) were not found in this case, the histopathological changes found in this patient are similar to those reported by Coons et al. in which $32 \%$ of hypothalamic hamartomas had predominantly diffuse architecture. ${ }^{8}$

\section{Postoperative Course}

The patient developed transient diabetes insipidus (DI) on postoperative day 0 requiring pediatric endocrinology consultation and continuous infusion of intravenous desmopressin for less than 24 hours. He then was transitioned to oral $0.05 \mathrm{mg}$ desmopressin every 12 hours for 24 hours and subsequently had spontaneous resolution of his DI. He was discharged home on postoperative day 4.

\section{Discussion}

To the best of our knowledge, this is the first report of

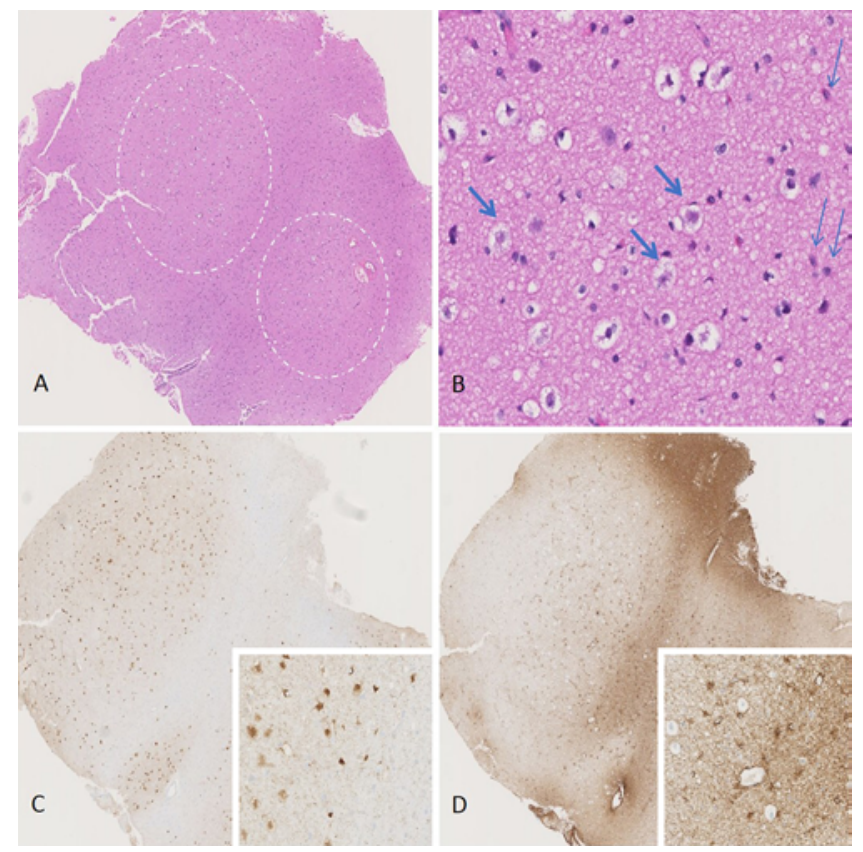

FIG. 4. Case 2. Photomicrographs of the hypothalamic hamartoma. Hematoxylin and eosin stain (A and $B$ ) demonstrates small foci of vague nodularity in the brain tissue at low power (A, circles), composed of medium-sized neurons with pericellular halo ( $B$, thick arrows), further highlighted by nuclear stain for Neu-N (C). These cells are embedded in finely vacuolated neuropil with a few reactive astrocytes ( $B$, thin arrows), further highlighted by GFAP staining (D). Magnifications $\times 2.5$ (A, C, and $D), \times 20(B$, insets of $C$ and $D)$. Figure is available in color online only. 


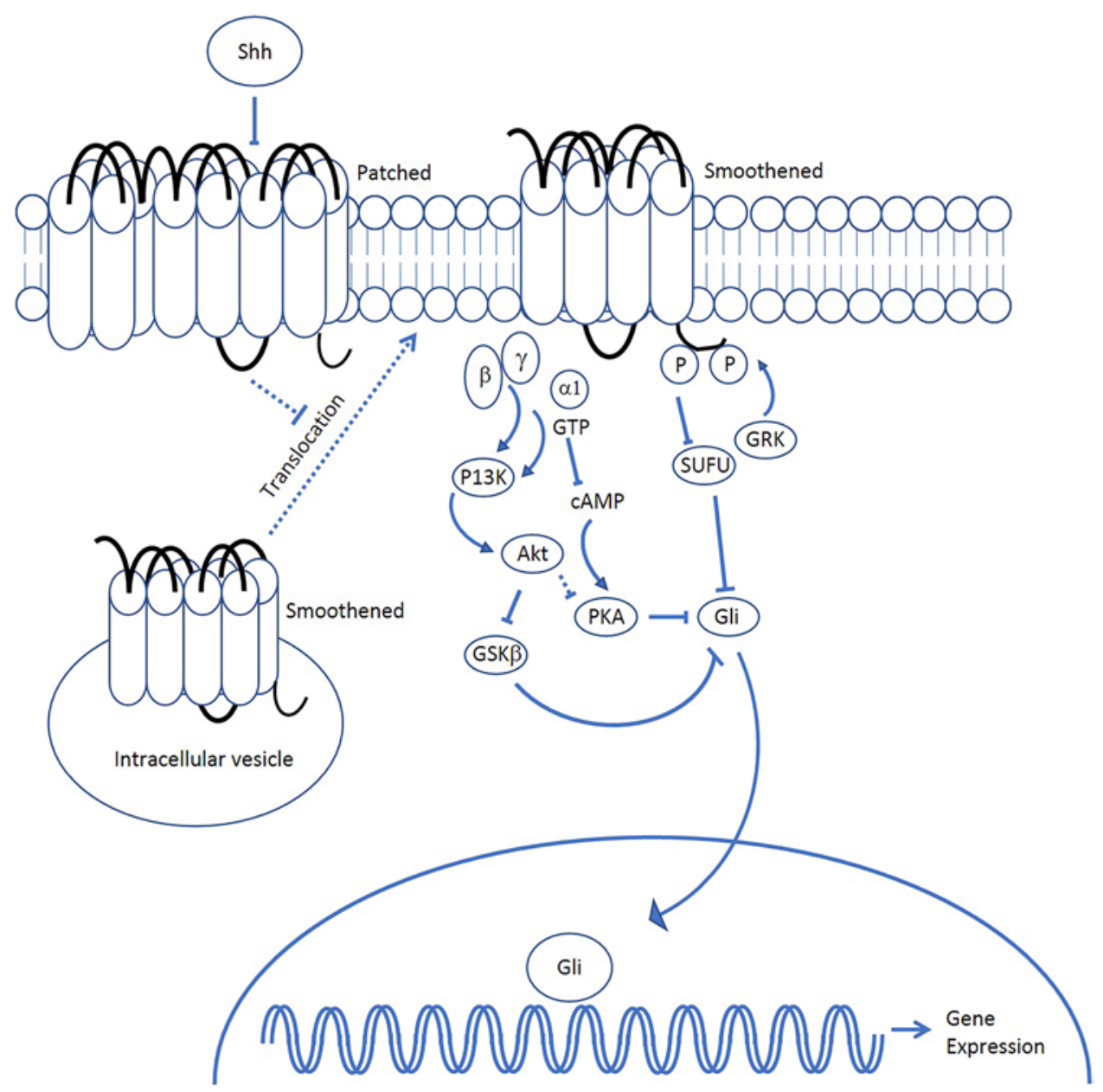

FIG. 5. Hedgehog signaling pathway. Binding of a hedgehog ligand such as Shh inhibits the Patched receptor and allows intravesicular Smoothened to translocate to the cell membrane. There it is activated by GRK2, which ultimately leads to downstream disinhibition of GLIs, allowing them to enter the nucleus to affect gene expression. Adapted by permission from Springer Nature: Nature Publishing Group, Nature Reviews Cancer, G-protein-coupled receptors and cancer by Dorsam RT and Gutkind JS, 2007.9

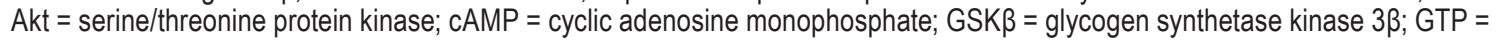
guanosine triphosphate; $\mathrm{PI} 3 \mathrm{~K}=$ phosphatidylinositol 3-kinase; $\mathrm{PKA}=$ protein kinase $\mathrm{A}$. Figure is available in color online only.

germline $S M O$ mutations causing a familial syndrome associated with hypothalamic hamartomas, polydactyly/ syndactyly, type I Chiari malformation, pituitary cyst, microcephaly, short stature, craniofacial abnormalities, and developmental delay. Both brothers have the same genotype, yet different phenotypes, indicating a syndrome with variable expressivity. However, both brothers have hypothalamic hamartomas and polydactyly, both phenotypes potentially being sufficient for consideration of underlying $S M O$ mutations in future patients.

The brothers' mother was heterozygous for the partial $S M O$ deletion and did not harbor the c.2291_2292delAG variant, while the father was heterozygous for the c.2291_ 2292 delAG variant and did not harbor the partial deletion. The boys' unaffected mother, the father's pathology, and their paternal family history suggest X-linked recessive inheritance of the maternal SMO partial deletion and autosomal dominant inheritance of the paternal c.2291_2292delAG variant in the SMO gene, both mutations needed to produce this clinical syndrome with variable expressivity.

\section{Review of the Hedgehog Pathway}

The Hh pathway is an evolutionarily conserved pathway that plays a critical role in embryogenesis ${ }^{2}$ with downstream effects on cell growth, patterning, and morphogenesis. ${ }^{28}$ The three mammalian morphogenic ligands that bind to the transmembrane Patched (PTCH) receptor and initialize the pathway include desert hedgehog (Dhh), Indian hedgehog (Ihh), and sonic hedgehog (Shh). Dhh expression primarily occurs in gonads, specifically within Sertoli cells ${ }^{5}$ and granulosa cells. ${ }^{41} I h h$ expression occurs in primitive endoderm, ${ }^{10}$ gastrointestinal tract, ${ }^{36}$ and differentiating chondrocytes. ${ }^{39}$ Shh is the most broadly expressed within the mammalian Hh pathway. ${ }^{37}$ It produces the only Hh ligand expressed in the CNS and plays a role in establishing left-right body differentiation, CNS development, somite patterning, eye development, and limb patterning. ${ }^{14}$ Shh is able to have widespread developmental effects by acting as either a morphogen or a mitogen depending on the type of receiving cell, dose of ligand received, and timing of exposure..$^{45}$ These proteins are translated by 
secreting cells and then act in an autocrine or paracrine fashion on receiving cells located up to $300 \mu \mathrm{m}$ away. ${ }^{23}$

The pathway begins by stoichiometric binding of a hedgehog ligand to the PTCH receptor, a 12-transmembrane domain protein that normally inhibits intracellular, vesicular SMO translocation to the cell membrane in its resting state ${ }^{35}$ Binding of an Hh ligand inhibits PTCH, releases SMO from its inhibition, and allows SMO to translocate to the cell surface (Fig. 5). ${ }^{9} \mathrm{SMO}$ is a seventransmembrane, $\mathrm{G}$ protein-coupled receptor that, when activated by $\mathrm{G}$ protein-coupled receptor kinase 2 (GRK2), proceeds to remove constituently active inhibition of GLIs $1-3$, allowing them to enter the nucleus to promote transcription of downstream target genes. ${ }^{7,22}$ Without an $\mathrm{Hh}$ ligand, SMO remains localized to endosomes in the cytoplasm, and GLI2 and GLI3 are bound by the Suppressor of Fused (SUFU) complex and phosphorylated by protein kinase A, leading to their cleavage. ${ }^{16}$ These cleaved proteins subsequently enter the nucleus where they repress transcription of downstream target genes. ${ }^{34}$

\section{Clinical Associations}

Mutations within the Hh pathway lead to varied pathologies depending on the protein affected. Several studies have reported Hh pathway activation in gliomas ${ }^{21}$ and esophageal, gastric, biliary tract, pancreatic, ${ }^{4}$ smallcell lung, ${ }^{40}$ and oral carcinomas. ${ }^{27}$ Genetic analyses have highlighted relationships between $S h h$ mutations and their association with holoprosencephaly, ${ }^{33}$ medulloblastoma, breast carcinoma, and basal cell carcinoma. ${ }^{29}$ Mutations in PTCH have been associated with nevoid basal cell carcinoma (Gorlin syndrome), ${ }^{17}$ sporadic basal cell carcinoma, medulloblastoma, ${ }^{32}$ trichoepithelioma, ${ }^{38}$ breast cancer, meningiomas, ${ }^{43}$ esophageal carcinoma, ${ }^{26}$ rhabdomyosarcoma, ${ }^{20}$ and bladder carcinoma. ${ }^{13}$ Historically, $S M O$ mutations have been associated with basal cell carcinoma, ${ }^{44}$ while GLI3 mutations have been associated with Greig cephalopolysyndactyly syndrome, ${ }^{42}$ Pallister-Hall syndrome, ${ }^{19}$ and postaxial polydactyly type A. ${ }^{31}$ In 2016 , Hildebrand et al. studied somatic mutations within spontaneous hypothalamic hamartomas and found 14 patients (37\%) had mutations in Hh genes, with only two patients having $S M O$ mutations. ${ }^{15}$ The germline $S M O$ mutations in our patients further substantiate these findings and further implicate dysfunction of the Hh pathway in the formation of hypothalamic hamartomas. The SMO partial deletion or variant may contribute to either a gain or loss of function: a potential gain of function by desensitizing SMO to PTCH inhibition and subsequently leading to a constitutively active pathway, or a potential loss of function by leading to partial inactivation of Shh signaling. Complete inactivation of the pathway is unlikely, given that Shh signaling is crucial for brain development, making a nonfunctional pathway incompatible with life. A potential mechanism for hamartoma growth and formation may parallel pathways studied in pancreatic fibroblasts, where $S M O$ deletion activates an Akt serine/threonine protein kinase pathway, leading to increased transcription of transforming growth factor alpha and its subsequent activation of epidermal growth factor receptors and their associated downstream effects. ${ }^{24}$
This is the first report of a familial syndrome involving germline mutations in the $S M O$ gene and the second familial syndrome associated with hypothalamic hamartomas. Further work must be completed to better understand this pathway and new clinical syndrome, including its mode of inheritance, prevalence, spectrum of clinical presentation, and natural progression, prior to development of any potential therapies.

\section{Acknowledgments}

We thank Julia Prusik for her assistance and guidance throughout the IRB application process.

\section{References}

1. Arita K, Ikawa F, Kurisu K, Sumida M, Harada K, Uozumi $\mathrm{T}$, et al: The relationship between magnetic resonance imaging findings and clinical manifestations of hypothalamic hamartoma. J Neurosurg 91:212-220, 1999

2. Bellusci S, Furuta Y, Rush MG, Henderson R, Winnier G, Hogan BL: Involvement of Sonic hedgehog (Shh) in mouse embryonic lung growth and morphogenesis. Development 124:53-63, 1997

3. Berkovic SF, Andermann F, Melanson D, Ethier RE, Feindel W, Gloor P: Hypothalamic hamartomas and ictal laughter: evolution of a characteristic epileptic syndrome and diagnostic value of magnetic resonance imaging. Ann Neurol 23:429-439, 1988

4. Berman DM, Karhadkar SS, Maitra A, Montes De Oca R, Gerstenblith MR, Briggs K, et al: Widespread requirement for Hedgehog ligand stimulation in growth of digestive tract tumours. Nature 425:846-851, 2003

5. Bitgood MJ, Shen L, McMahon AP: Sertoli cell signaling by Desert hedgehog regulates the male germline. Curr Biol 6:298-304, 1996

6. Brandberg G, Raininko R, Eeg-Olofsson O: Hypothalamic hamartoma with gelastic seizures in Swedish children and adolescents. Eur J Paediatr Neurol 8:35-44, 2004

7. Chen W, Ren XR, Nelson CD, Barak LS, Chen JK, Beachy PA, et al: Activity-dependent internalization of smoothened mediated by beta-arrestin 2 and GRK2. Science 306:22572260, 2004

8. Coons SW, Rekate HL, Prenger EC, Wang N, Drees C, Ng YT, et al: The histopathology of hypothalamic hamartomas: study of 57 cases. J Neuropathol Exp Neurol 66:131-141, 2007

9. Dorsam RT, Gutkind JS: G-protein-coupled receptors and cancer. Nat Rev Cancer 7:79-94, 2007

10. Dyer MA, Farrington SM, Mohn D, Munday JR, Baron MH: Indian hedgehog activates hematopoiesis and vasculogenesis and can respecify prospective neurectodermal cell fate in the mouse embryo. Development 128:1717-1730, 2001

11. Freeman JL, Coleman LT, Wellard RM, Kean MJ, Rosenfeld JV, Jackson GD, et al: MR imaging and spectroscopic study of epileptogenic hypothalamic hamartomas: analysis of 72 cases. AJNR Am J Neuroradiol 25:450-462, 2004

12. Hall JG, Pallister PD, Clarren SK, Beckwith JB, Wiglesworth FW, Fraser FC, et al: Congenital hypothalamic hamartoblastoma, hypopituitarism, imperforate anus and postaxial polydactyly-a new syndrome? Part I: clinical, causal, and pathogenetic considerations. Am J Med Genet 7:47-74, 1980

13. Hamed S, LaRue H, Hovington H, Girard J, Jeannotte L, Latulippe E, et al: Accelerated induction of bladder cancer in patched heterozygous mutant mice. Cancer Res 64:19381942,2004

14. Hammerschmidt M, Brook A, McMahon AP: The world according to hedgehog. Trends Genet 13:14-21, 1997 
15. Hildebrand MS, Griffin NG, Damiano JA, Cops EJ, Burgess R, Ozturk E, et al: Mutations of the Sonic Hedgehog pathway underlie hypothalamic hamartoma with gelastic epilepsy. Am J Hum Genet 99:423-429, 2016

16. Humke EW, Dorn KV, Milenkovic L, Scott MP, Rohatgi R: The output of Hedgehog signaling is controlled by the dynamic association between Suppressor of Fused and the Gli proteins. Genes Dev 24:670-682, 2010

17. Johnson RL, Rothman AL, Xie J, Goodrich LV, Bare JW, Bonifas JM, et al: Human homolog of patched, a candidate gene for the basal cell nevus syndrome. Science 272:16681671,1996

18. Kahane P, Ryvlin P, Hoffmann D, Minotti L, Benabid AL: From hypothalamic hamartoma to cortex: what can be learnt from depth recordings and stimulation? Epileptic Disord 5:205-217, 2003

19. Kang S, Graham JM Jr, Olney AH, Biesecker LG: GLI3 frameshift mutations cause autosomal dominant PallisterHall syndrome. Nat Genet 15:266-268, 1997

20. Kappler R, Bauer R, Calzada-Wack J, Rosemann M, Hemmerlein B, Hahn H: Profiling the molecular difference between Patched- and p53-dependent rhabdomyosarcoma. Oncogene 23:8785-8795, 2004

21. Kinzler KW, Bigner SH, Bigner DD, Trent JM, Law ML, O'Brien SJ, et al: Identification of an amplified, highly expressed gene in a human glioma. Science 236:70-73, 1987

22. Kinzler KW, Vogelstein B: The GLI gene encodes a nuclear protein which binds specific sequences in the human genome. Mol Cell Biol 10:634-642, 1990

23. Lewis PM, Dunn MP, McMahon JA, Logan M, Martin JF, St-Jacques B, et al: Cholesterol modification of sonic hedgehog is required for long-range signaling activity and effective modulation of signaling by Ptc1. Cell 105:599-612, 2001

24. Liu X, Pitarresi JR, Cuitiño MC, Kladney RD, Woelke SA, Sizemore GM, et al: Genetic ablation of Smoothened in pancreatic fibroblasts increases acinar-ductal metaplasia. Genes Dev 30:1943-1955, 2016

25. Luginbuhl AJ, Campbell PG, Evans J, Rosen M: Endoscopic repair of high-flow cranial base defects using a bilayer button. Laryngoscope 120:876-880, 2010

26. Maesawa C, Tamura G, Iwaya T, Ogasawara S, Ishida K, Sato $\mathrm{N}$, et al: Mutations in the human homologue of the Drosophila patched gene in esophageal squamous cell carcinoma. Genes Chromosomes Cancer 21:276-279, 1998

27. Nishimaki H, Kasai K, Kozaki Ki, Takeo T, Ikeda H, Saga $\mathrm{S}$, et al: A role of activated Sonic hedgehog signaling for the cellular proliferation of oral squamous cell carcinoma cell line. Biochem Biophys Res Commun 314:313-320, 2004

28. Niswander L, Jeffrey S, Martin GR, Tickle C: A positive feedback loop coordinates growth and patterning in the vertebrate limb. Nature 371:609-612, 1994

29. Oro AE, Higgins KM, Hu Z, Bonifas JM, Epstein EH Jr, Scott MP: Basal cell carcinomas in mice overexpressing sonic hedgehog. Science 276:817-821, 1997

30. Pinheiro-Neto CD, Ramos HF, Peris-Celda M, FernandezMiranda JC, Gardner PA, Snyderman CH, et al: Study of the nasoseptal flap for endoscopic anterior cranial base reconstruction. Laryngoscope 121:2514-2520, 2011

31. Radhakrishna U, Wild A, Grzeschik KH, Antonarakis SE: Mutation in GLI3 in postaxial polydactyly type A. Nat Genet 17:269-271, 1997

32. Raffel C, Jenkins RB, Frederick L, Hebrink D, Alderete B, Fults DW, et al: Sporadic medulloblastomas contain PTCH mutations. Cancer Res 57:842-845, 1997

33. Roessler E, Belloni E, Gaudenz K, Jay P, Berta P, Scherer SW, et al: Mutations in the human Sonic Hedgehog gene cause holoprosencephaly. Nat Genet 14:357-360, 1996

34. Sasaki H, Nishizaki Y, Hui C, Nakafuku M, Kondoh H:
Regulation of Gli2 and Gli3 activities by an amino-terminal repression domain: implication of Gli2 and Gli3 as primary mediators of Shh signaling. Development 126:3915-3924, 1999

35. Stone DM, Hynes M, Armanini M, Swanson TA, Gu Q, Johnson RL, et al: The tumour-suppressor gene patched encodes a candidate receptor for Sonic hedgehog. Nature 384:129-134, 1996

36. van den Brink GR: Hedgehog signaling in development and homeostasis of the gastrointestinal tract. Physiol Rev 87:1343-1375, 2007

37. Varjosalo M, Taipale J: Hedgehog: functions and mechanisms. Genes Dev 22:2454-2472, 2008

38. Vorechovský I, Undén AB, Sandstedt B, Toftgård R, StåhleBäckdahl M: Trichoepitheliomas contain somatic mutations in the overexpressed PTCH gene: support for a gatekeeper mechanism in skin tumorigenesis. Cancer Res 57:46774681, 1997

39. Vortkamp A, Lee K, Lanske B, Segre GV, Kronenberg HM, Tabin CJ: Regulation of rate of cartilage differentiation by Indian hedgehog and PTH-related protein. Science 273:613622,1996

40. Watkins DN, Berman DM, Burkholder SG, Wang B, Beachy PA, Baylin SB: Hedgehog signalling within airway epithelial progenitors and in small-cell lung cancer. Nature 422:313317, 2003

41. Wijgerde M, Ooms M, Hoogerbrugge JW, Grootegoed JA: Hedgehog signaling in mouse ovary: Indian hedgehog and desert hedgehog from granulosa cells induce target gene expression in developing theca cells. Endocrinology 146:35583566,2005

42. Wild A, Kalff-Suske M, Vortkamp A, Bornholdt D, König R, Grzeschik KH: Point mutations in human GLI3 cause Greig syndrome. Hum Mol Genet 6:1979-1984, 1997

43. Xie J, Johnson RL, Zhang X, Bare JW, Waldman FM, Cogen $\mathrm{PH}$, et al: Mutations of the PATCHED gene in several types of sporadic extracutaneous tumors. Cancer Res 57:23692372, 1997

44. Xie J, Murone M, Luoh SM, Ryan A, Gu Q, Zhang C, et al: Activating Smoothened mutations in sporadic basal-cell carcinoma. Nature 391:90-92, 1998

45. Yang Y, Drossopoulou G, Chuang PT, Duprez D, Marti E, Bumcrot D, et al: Relationship between dose, distance and time in Sonic Hedgehog-mediated regulation of anteroposterior polarity in the chick limb. Development 124:43934404, 1997

\section{Disclosures}

The authors report no conflict of interest concerning the materials or methods used in this study or the findings specified in this paper.

\section{Author Contributions}

Conception and design: Rubino, Adamo. Acquisition of data: all authors. Analysis and interpretation of data: all authors. Drafting the article: Rubino, Qian. Critically revising the article: all authors. Reviewed submitted version of manuscript: all authors. Approved the final version of the manuscript on behalf of all authors: Rubino. Administrative/technical/material support: Rubino. Study supervision: Rubino.

\section{Correspondence}

Sebastian Rubino: Albany Medical Center, Albany, NY.rubinos@ amc.edu. 